\title{
DOCUMENTÁRIO
}

\section{UMA PRIMEIRA TOMADA DE CONSCIÊNCIA DO DESENVOLVIMENTO BRASILEIRO.}

\author{
JOSE FERREIRA CARRATO \\ Do Depaitamento de História da Faculdade de Filoso- \\ fia, Letras e Ciências Humanas da Univcrsidade de São \\ Paulo.
}

Nas Instrucçoens q. El Rey MeuSnr. manda dar pelo Real Erario ao Gov .or eCap am Genr.l de V. a Rica aRespeito da admenistração, eArredacadação daFazd.a Real, o Marquês de Pombal, o todo-poderoso Ministro de El-Rei D. José I, assim principia taxativamente, dirigindo-se ao Governador D. Antônio de Noronha, da Capitania de Minas Gerais, em 1775:

"O Principal objecto q. deveter prez.te q.m teve ahonra de ser encarregado dequalquer Governo Ultramarino, he aboa admenistração das Rendas Reacs, deque tanto depende asegurança pub:ica, por serem as Conquistas afonte deq. emanão as Riquezas, $q$. fazem Respeitado eopulento oEstado (giifos nossos). O augmento das Rendas Reaes, principalm.te depende da Agricultura, daIndustria, dafacil Circulação doComcrcio, daboa aRecadação da Real Fazd.a."

E, em seguida, explica donde procede, em Minas, êsse

"augmento das Rendas Reaes": "São o Comercio e Agricultura as duas fazes, nas quaes mais doque em outras secostumão Sustentar os tres Rendim.tos mais consideraveis da Cap.nia das Minas Geraes, quaes são os Rendim.tos do Quinto, das Entradas, e dos Dizimos". (Grifos nossos) (1).

E esc'arece, bem de acôrdo com o pensamento oficial da Côrte de Lisboa, em que consiste o quinto do ouro:

"Consiste o direito Senhorial dos Quintos nas Cem arrobas doOuro q. os Povos dadita Cap.nia offerecerão aSua Mag.de p.a Se Remirem daCapitação comque erão vexados: Aceitou Sua Mag.de be-

(1). - Códice 211, do Arquivo Público Mineiro (Belo Horizonte), fls. 1. 
nignam.te esta oferta mandando promulgar p.a esteffeito aLey de 3 de Dez.bro de 1750: Com o tempo seforão esquecendo os mesmos Povos deste incomparavel beneficio e derão emprocurar enseijos dese eximirem dehum Direito q. por todas as Leys hé devido ao Soberano, ¥. hé geralm.te util aos mesmos Povos, eque elles mesmos impuzerão asi proprios por meyodehua derrama, no Cazo denão produzir as Cem arrobas deOuro o Rendim.to das Cazas de fundição das Comarcas dam.ma Cap.nia; lembrandolhes aSua ambição eadotando como mais proprio p.a conseguir Seus desliaes intentos oCaminho pessimo, eabominavel dos Extravios doOuro, sendo tãofrequentes de diaemdia tanto mayores os Roubos q. desde o anno de 1769 setem Conhecido deminuição consideravel no Referido Rendim.to" (2).

Eis um documento dos mais lúcidos do trágico, do imenso engano, $\mathrm{em}$ que laboraram sempre as administrações régias, mesmo as mais objetivas, em relação à realidade política e econômica das Minas Gerais, a Meca do ouro, no século XVIII. E' uma visão completamente destorcida do que era, do que valia e de como se comportava a grande Capitania. A coisa resulta ainda mais grave, quando nos lembramos de que o documento era uma "instrucção" de govêrno, uma verdadeira plataforma, um plano de trabalho, que o Gabinete de El-Rei entregava a um dos governadores escolhidos para vir administrar a Capitania, com o fito de cumprir-lhe os ditames fundamentais. Nem é necessária, tão clara é o seu texto, qualquer hermenêutica sôbre essas "instrucçoens" pombalinas. O que nelas avulta é sempre uma constante fixa, a obsessão do ouro, daquelas

"riquezas, q. fazem Respeitado eopulento oEstado",

a que se refere tão expressivamente o Marquês de Pombal, em seu estilo característico. Mas, a idéia fixa não é só de Pombal, é de todos os governos régios, prevalece em todos os documentos da época. Também, em sua Expozição sobre o Estado de decadencia da Capitania de Minas Geraes, emeyos de remedialo, cinco anos depois, em 1780, quando a crise da produção aurífera começa a assumir proporções irremediáveis, o Governador D. Rodrigo José de Menezes, aliás governante esclarecido e bem intencionado, volta a bater na mesma tecla, na mesma errada tecla de que tudo, em Minas, se resume na produção do ouro e nada mais: a Capitania não tem outra produção — diz êle -

(2). - Idem, fls. 2 . 
"ela não hé propriamente dita nem agricula nem comerciante. O Ouro tão util para Portugal, hé a produção destas ricas Montanhas" (3).

Ora, a causa da ruína da produção aurífera e, pois, tôda a crise política, econômica e moral que desabou sôbre a Capitania de Minas Gerais, nos derradeiros decênios coloniais, residem nesse grave êrro de perspectiva administrativa. Jamais a Administração Régia chegou a compreender que a produção do ouro deveria ser a soma de múltiplas e diversas providências administrativas, científicas, técnicas, financeiras, e até de ordem moral e humana; que os domínios ultramarinos poderiam oferecer outras riquezas que não aquelas colhidas pelo simplismo brutal da predação colonialista ou pelo implacável fisco mercantilista. O mal que daí resultou foi irreparável, traduzido pela sistemática inoperância dos governos locais, no sentido de fazer algo que sequer atenuasse aquela política desastrosa. Via de regra, os governos coloniais das Capitanias foram incapazes. Ou melhor, foram antes governos cegos, que jamais viram a realidade do seu próprio objeto.

Principalmente os de Minas Gerais. E' verdade que êsses governos ressentiam-se menos das pessoas que os exerciam do que do próprio regime político que os mantinha. Naquela monarquia absoluta e paternal portuguêsa, os governadores eram de livre escolha do soberano: eram livremente nomeados, assim como livremente despedidos. Ficamos impressionados com o Aviso de demissão, que o Ministro Martinho de Melo e Castro mandou, em fins de 1779, ao Governador D. Antônio de Noronha:

"Sua Mag.de houve por bem nomear aD. Rodrigo Jozé de Menezes p. SucederaV. S.a no Gov.o dessaCapitania" (4).

E só. Acrescenta apenas que o Governador demitido deve aproveitar a nau de guerra que traz o nôvo,

"sem esperar que elle ahy chegue, afim deSeantecipar á partidadadita Nau", (...) "que hade esperar (aqui a pressa acaba...) pelos Quintos"

de ouro, que serão enviados a Lisboa. Não havia qualquer critério na escôlha dêsses governadores, a não ser o jôgo palaciano das influências das grandes famílias nobres, de que resultavam as nomeações ou as dispensas, conforme soprassem os ventos dessas influências. Embora fôssem êsses cargos, quase sempre, rendosas sinecuras, não se

(3). - Idem, fls. 3 .

(4). - Códice 224, do APM. 
seguia que fôssem necessàriamente prêmios aos escolhidos. Às vêzes, eram ensejos para El-Rei descartar-se dos elementos menos interessantes ao seu convívio, pelo tempo que o quisesse.

Em Minas, iria ser muito raro o provimento de um capitão-general, em atenção direta aos interêsses da terra, naquilo que dissesse respeito, v. g., à solução ou a atenuação da crise da produção do ouro. Há quase nenhuma notícia de governantes que chegassem especialmente para resolver um problema qualquer da Administração: o exemplo de Antônio de Albuquerque, que subiu às Minas, para debelar a "guerra" dos Emboabas, é pura exceção. Os governadores sempre vieram da Côrte olìmpicamente jejunos sôbre o que fazer de sua administração: as "instrucçoens" para o govêrno da Capitania - preciosos documentos da literatura histórica mineira - que também excepcionalmente se prescreviam a alguns governadores, chegavam-lhes às mãos quando já nomeados ou sem tempo para as estudarem (caso por elas se interessassem) convenientemente.

Dessas "instrucçoens", nenhuma se apresenta tão completa e bem informada como a Instrução para o govêrno da Capitania de Minas Gerais, escrita em 1780, pelo Desembargador José João Teixeira, na qual os deveres de um bom governante daquela Capitania aparecem como os seguintes: ter

\footnotetext{
"as virtudes que honrão os particulares"; ter os "corhecimentos gerais que respeitão aos Governos"; proteger "os suditos que forem benemeritos"; não "intrometer-se na direção dos costumes particulares" dos mesmos súditos, mas sim na "dos que são gerais"; "conservar os povos em sossego"; "promover o comércio"; "reprimir os régulos"; "ouvir com afabilidade os humildes"; "desprezar a lizonja"; "proceder sem precipitação"; e "zelar os interesses Reais, sem vexação dos Povos" (5).
}

Acontecia afortunadamente, uma vez ou outra, que os governadores escolhidos tomavam-se de entusiasmo pelo cargo e enchiam a cabeça de generosos planos de govêrno: iriam para a desconhecida terra de além-mar, nova e rica de possibilidades, onde fariam mil e uma coisas, e tantas, que haveriam de arrancá-las da barbárie em que jaziam, que isso de barbárie era a única coisa que delas sabiam. Chegavam aqui e tomavam posse, com grandes festas. Metiam mãos à obra. Mas aí é que começavam a surgir as dificuldades: a dura realidade principiava a crescer e ia, aos poucos, afogando as fagueiras ilusões trazidas da Europa. Não era fácil vencer a barbárie bruta em que vivia o Brasil colonial. Aí, êles acomodavam-se e acabavam por

(5). - Códice 211, cit., fls. 105. 
cair na apatia geral, naquele "pasmo" vegetativo em que viviam mergulhados os povos do tempo, a que se refere o velho Diogo Pereira Ribeiro de Vasconcelos. Governadores que deram de si na administração mineira podem ser aqui enumerados: o brasileiro e grande homem público Antônio de Albuquerque (1709-1713), que pacificou paulistas e emboabas e erigiu as primeiras vilas da Capitania; D. Lourenço de Almeida (1721-1732), veterano militar de "grandes Serviços na Azia", homem prudente, que conciliou os interêsses reais com os dos povos, fazendo-os cumprir, sem violência, suas obrigações de vassalos; o Conde de Valadares (D. José Luís de Menezes Abranches Castelo Branco e Noronha) (1768-1773), menor de vinte e cinco anos ao assumir a governadoria, mas que se revelaria talvez o mais dinâmico e completo administrador das Minas coloniais, saneando a máquina do govêrno, regulando os contátos com a justiça, corrigindo os males da sonegação e do contrabando, exterminando para os confins da Capitania os vadios, fazendo-se presente, enfim, em todos os setores da administração; D. Antônio de Noronha (1775-1780), o primeiro Capitão-General que tentou superar a crise de mineração pela introdução de processos técnicos e econômicos. tais sejam obras montanísticas no Ribeirão do Carmo e em São Miguel de Percicaba, a fundação de colônias agrícolas no sertão (Cuieté), visando empregar os vadios em atividades úteis, a fundação de uma associação cooperativa dos mineiros do Rio das Velhas, para exploração comum das lavras, etc.:

\footnotetext{
"a Capitania de Minas perdeu nele hum restaurador - depöe um magistrado contemporâneo seu - se fosse conservado no governo mais trez anos se veria mudada a face dos interesses daquela Provincia" (6);
}

D. Rodrigo José de Menezes (1780-1783), que iria prosseguir os planos modernos de Noronha, além de adjudicar a si o mérito de ser o primeiro homem de govêrno colonial que tentou iniciar a produção do ferro em Minas, não apenas para socorrer as fábricas de nineração, como também para aproveitar as incomensuráveis jazidas de minério ferrífero ali existentes; e, finalmente, D. Bernardo José de Lorena, Conde de Sarzedas (1797-1803), filho da Marquesa nova de Távora (que as más línguas assoalhavam ser filho de D. José I), que não foi sòmente o galanteador perigoso das donzelas incautas da Capitania (como o fôra em São Paulo) e grande amigo de festas e prazeres, mas também um governador capaz e sensato, secundando com diligên-

(6). - Instrução para o Govêrno da Capitania de Minas Gerais. "Revista do Arquivo Público Mineiro" (RAPM), Belo Horizonte, Imprensa Oficial, ano VIII, p. 403 . 
cia a obra notável da busca científica das riquezas e recursos naturais da Capitania promovida pelo Ministro D. Rorigo de Sousa Coutinho, e engendrando tôda a sorte de artifícios junto da Côrte de Lisboa (inclusive pagando secretas seus ali) para fazer carreira e fortuna, mesmo à custa do tráfico de escravos (7).

Parece que são êsses os governadores mineiros que, numa rápida enumeração como esta, merecem destaque especial, pelo acervo d benefícios com que aquinhoaram a Capitania. Não nos esqueçamos, todavia, de que haveriam de ter vivido, mais ou menos, a natural sequiência daquelas três fases da atividade administrativa dos bons capitães-generais, segundo a pitoresca classificação de João Carlos Augusto de Oyenhausen (aliás ex-Governador das Capitanias de Mato Grosso e de São Paulo): a da febre com delírio (que era quando concebiam seus nobres planos de govêrno), a da febre sem delírio (quando começavam a ruir suas ilusões) e a da prostração (quando, ao fim de seus governos, não se interessavam por mais nada) (8) ...

Desconfiamos, porém, que vários dêles já vieram diretamente para a fase de prostração ou, melhor, do dolce far niente, de que poucas vêzes saíram para fazer alguma coisa de útil para os seus governados. Para fazermos justiça, vale a pena recordar os atos administrativos de alguns dos capitães-generais não lembrados acima, que foram verdadeiramente dignos da posteridade: aquêle do Conde de Assumar (D. Pedro de Almeida) (1717-1721), quano pôs em ação a fôrça de que dispunha, no momento que julgou asado, vencendo as facções sediciosas, atitude que pôde garantir largos anos de tranqüilidade para o govêrno do seu sucessor; aquêle do Conde das Galveias (D. André de Melo e Castro) (1732-1735), negando-se a cumprir as ordens régias do impôsto da capitação, que considerava ruinoso para os mineradores; o de Gomes Freire de Andrade (1735-1763), grande homem fora de Minas Gerais, que mal governou, em tantos anos de efetiva governadoria e quase contínua ausência da Capitania, ao iniciar a política de proteção dos jovens de talento, que teria encaminhado aos estudos de além-mar; o do bom General Luís Diogo Lôbo da Silva (1763-1768), protetor da Santa Casa de Vila Rica, a fazer a mais longa viagem do tempo (aos sertões de Jacuí), em que o acompanhou o poeta Cláudio Manuel da Costa, então Secretário do Govêrno, para melhor conhecer e dominar os problemas do descaminho e da exploração de novas minas de ouro, aliás em pura perda; o do presunçoso

(7). - Fundos da Biblioteca Nacional de Lisboa, Coleção Pombalina, Cartas de Bernardo José de Lorena, $\mathrm{n}^{\circ} 11$ :

(8). - Saint-Hilaire (Augusto de), Viagem pelas Províncias do Rio de Janeiro e Minas Gerais. Edição Brasileira, São Paulo, Companhia Editôra Nacional (Brasiliana), 1938, 2 v., t. I, p. 304. 
Antônio Carlos Furtado de Mendonça, fazendo cobrar, pela primeira vez na Capitania, o subsídio literário (sem mérito nenhum de sua parte, pois obedecia a ditames superiores).

Numa simples enumeração como esta, pouco teríamos que anotar dos últimos governadores, que exerceram seu mandato já no século XIX, não fôsse a variada colaboração que lhes deram, em não menos variados setores da Administração, os chamados doutores mineiros de Coimbra, inaugurando no govêrno técnicas e processos científicos, como nunca se viram até então. Aliás. essa colaboração dos doutores chegados da Europa principia já nos derradeiros anos da centúria setecentista, principalmente depois que assume seu elevado pôsto, em 1796, no Govêrno do Príncipe Regente. D. Rodrigo de Sousa Coutinho, mais tarde Conde de Linhares, bisneto que foi do bandeirante mineiro Matias Barbosa da Silva, sesmeiro do vale do Paraibuna e fundador de Barra Longa. Tão logo feito Ministro, o futuro Conde de Linhares rodeou-se de inúmeros brasileiros residentes em Lisboa,

\footnotetext{
"ouvindo-os, e facilitando-lhes a imprensa", que, "quase em favor dêles foi declarada livre" (Varnhagen),
}

pela criação da Tipografia Calcográfica e Tipoplástica do Arco do Cego, que D. Rodrigo entregou à direção do notável brasileiro Frei José Mariano da Conceição Veloso. Vimos como foi verdadeiramente incansável o grande mineiro na elaboração, tradução e edição de obras nacionais e estrangeiras, de preferência aquelas que diziam respeito ao progresso e ao desenvolvimento da agricultura brasileira, sem falar num número muito avultado de pequenas memórias e folhetos, que eram enviados oficialmente pelas diferentes capitanias. Temos, por exemplo, provas de várias remessas dêsses impressos aos Governadores da Capitania de Minas Gerais,

\footnotetext{
"destinados a instruir os Habitantes do Brazil emvarios artigos de Agricultura, e outros objectos, deque podem tirar muitas utilidades" (9),
}

como aquela de 1 o de abril de 1799 , que inclui trezentos folhetos, sôbre álcalis fixos (potassa), cravo girofe, urumbeba (?) e até exemplares do De rebus rusticis, a preços bem populares. Em outra parte dêste trabalho, referimo-nos aos principais trabalhos que publicou Frei Veloso. Em tôrno dêste, agruparam-se vários intelectuais brasileircs, que também deram a lume publicações suas, tais como Antônio Carlos Ribeiro de Andrada, José Feliciano Fernandes Pinheiro, Vicente Coe-

(9). - Códice 288, do APM, fls. 17. 
Iho de Seabra Silva Teles (que Rodolfo Garcia, erradamente, em nota na História Geral do Brasil, de Varnhagen, corrige para Vicente Coelho da Silva Seabra e Teles), Manuel Jacinto Nogueira da Gama e outros. Este último incluiria, em trabalho seu, em 1798, o elogio do Príncipe D. João e dos novos homens do Govêrno e suas realizações, verdadeiramente inovadoras, porque inspiradas muitas delas pelos cientistas, economistas, políticos e literatos que freqüentam a Côrte:

"Os meus conterrâneos, lembrados: - fundamenta o futuro Marquês de Baependi a sua dedicatória ao Príncipe Rcgente - os seus interêsses promovidos; a sua agricultura socorrida; a sua ignorância atalhada; o adiantamento dos seus conhecimentos $\mathrm{e}$ indústria; em conseqüência do incalculável benefício que acabam de receber com a publicação em linguagem de todos os escritos das nações mais iluminadas, pertencentes aos atuais gêneros da sua agricultura e comércio, e aos que de nôvo se podem introduzir; a facilidade das suas comunicações e correspondências, pelos correios do interior e marítimos; os exames e indagações filosóficas, que atualmente se fazem por todo o Brasil, de que já resultou, além de outras, a interessantíssima descoberta de nitreiras naturais; a formação de artificiais; (...) a publicação de obras científicas, e outras muitas sábias e benéficas disposições, incontestáveis argumentos de uma alma riquíssima de luzes, e de um coração cheio de bondades; que motivos, Senhor, não são para minha admiração, e para o mais profundo respeito, e gratidão da minha alma!" (10).

Com efeito, a política do Príncipe D. João, superiormente aconselhada por D. Rodrigo de Sousa Coutinho, é mesmo de entusiasmar essa gente letrada, cuja assessoria o esclarecido Ministro não dispensa nunca ou cuja colaboração êle faz questão de obter. Assim é que o médico e botânico Manuel de Arruda Câmara, estimulado pelo Govêrno, mete-se pelo Pernambuco a dentro, buscando e classificando mais de cem plantas úteis, publica trabalho acêrca da cultura do algodão, e outro sôbre plantas filamentosas. Já tivemos ensejo de dizer algo sôbre o mineiro de Caeté, José de Sá Bitencourt, irmão do Intendente Câmara — que foi condiscípulo de José Bonifácio, em Coimbra, e sôbre quem êsse colega disse que era mais bem dotado que Câmara (11) - que percorreu os bosques, mimosos, agrestes e catan-

(10). - Varnhagen (Francisco Adolfo de), História Geral do Brasil. 7a. edição, São Paulo, Melhoramentos, s/d., 6t, t. V, p. 15.

(11). - 1a. Carta de José Bonifácio de Andrada e Silva ao Conde de Funchal, em 30 de julho de 1812, fls. 3 (Arquivo do Instituto Histórico e Geográfico Brasileiro, do Rio de Janeiro, Doc. $n^{9} 4.845-\mathrm{C}$, lata 191). 
duvas dos sertões da Bahia, e escreveu sôbre as plantações de al@odão; e sôbre José Vieira Couto, suas viagens e suas obras. Mas, pouco falamos dêsse bahiano notável que foi Baltasar da Silva Lisboa, outro dos intelectuais bafejados pela audiência da Côrte de D. João, cujas idéias e escritos sôbre terras e matas da marinha e assuntos florestais foram acatadas pelo Govêrno; e também do seu grande irmão. José, o futuro Visconde de Cairú, discípulo e seguidor das idéias econômicas de Adam Smith, que propôs ao Príncipe Regente, em 1808. o franqueamento dos portos do Brasil às nações do mundo; e do Bispo D. José Joaquim da Cunha de Azeredo Coutinho, profundo conhecedor dos problemas econômicos brasileiros. um dos quais ajudon a solver com seus escritos, o monopólio do sal, e ajudando José Bonifácio a derrubar outro, o da pesca das baleias; e do publicista Hipólito José da Costa, de idéias mais avançadas que todos os demais, pois foi dos primeiros a apregoar a permanência da Côrte no Brasil e, conseguintemente, a nossa Independência. Todos êsses cientistas, políticos e letrados fizeram parte do ilustrado círculo de $\mathrm{D}$. Rodrigo e colaboraram em muitas das suas melhores iniciativas de govêrno. Era uma verdadeira revolução essa, a de dirigentes da Administração Régia ouvirem a homens de ciência e letras em assuntos políticos.

Um dêsses homens de ciência, brasileiro, deveras acatado nas altas esferas da Côrte, era o paulista José Bonifácio de Andrada e Silva, eminente mineralogista, que fôra aquinhoado com uma cadeira na Universidade de Coimbra, recebera o títu'o de Desembargador e dirigia umas obras de canalização do Rio Mondego. Mas, além de sua rígida formação doméstica e escolar, na Vila de Santos, deveria ter recebido também, quando estudante em Coimbra, como os demais condiscípulos brasileiros, aquela nova formação cívica, aquêle "ensino para servir a sua pátria" (Ribeiro Sanches), dado com tanto empenho pela Universidade reformada, que criara no espírito de todos um geral anseio de servir bem ao seu País, lá na Metrópole, e aqui, do outro lado do mar. José Bonifácio, então, era um fervoroso patriota e ansiava por vo'tar à terra natal:

"Quero offerecer-me à V. Ex.a - eis como escrevia êle, em 1812, ao Conde de Funchal, irmão de D. Rodrigo (12) - p.a algua coiza, q. possa ser util ao Estado e ao Brazil, onde nasci, e q. dezejo anciozam.te servir; porq. conheço o q. pode e deve vir a ser hum dia, se tivermos juizo".

Já quase cinqüentão, está cansado de permanecer em Portugal e, mesmo, desiludido, pois declara, em outra carta, estar possuído de

(12). - Eadem, fls. 4. 
"algua zanguinha (!) de ver q. os meos serviços como Lente, Magistrado, e soldado da Patria até agora não tem merecido a menor contemplação, ao mesmo tempo q. tanta gente não sei como tem sido honrada, e despachada" (13).

Isto, e a saudade do Brasil lhe roem a consciência por não ter aproveitado uma licença real para regressar, quando então poderá realizar os planos que tem para o seu País:

"Poderia nelle, se me dessem tempo e me deixassem as mãos livres - escreve êle - hir plantar as artes e a agricultura Europea, por em administração regular os bosques, crias, pescarias, esalgações, e experimentar o meo projecto de civilizar à Christan os Indios" (14);

embora acredite, em relação à raça brasileira em formação, que

"amalgamação m.to difficil será a liga de tanto metal heterogêneo, como brancos, mulatos, pretos livres e escravos, Indios, etc., em hum corpo solido e politico" (15), sugere por isso mesmo "q. se removão os obstaculos da industria, que a razão e as sciencias ganhem pés diariam.te - educação physica e gymnastica, por q. o clima e a fertilid.e do torrão a requerem imperiobam.te - não empecer os voos espontaneos da activid. de particular - premio certo e pronto aos benemeritos, e castigo aos patifes - nada de castellos de cartas de jugar q. só divertem crianças"

e desce a minúcias, chegando a sugerir ao Conde do Funchal até o pessoal científico a empregar-se na emprêsa do Brasil, tão interessantes, que não nos furtamos à tentação de transcrevê-las na íntegra:

"V. Ex.a quer q. The aponte alguns homens de talento e capacid.e, e o q. mais hé de probid.e q. possa empregar em viagens Botanicas, Mineralogicas, e Chimicas pela vasta e rica terra incognita Brazilica. - começa o futuro Patriarca - Com effeito tem m.ta razão de querer nacionaes, pois foi vergonha empregar o Inglez Mawe, p. a se decidir se húa pedra era um diamante, ou hum calháo - com todo o rigor e sizo, ahi vai o pequeno catalogo q. achei. P.a a Botanica he excellente o Lente substituto Antonio Jozé das Neves em conhecim.to etalento o julgo $m$.to superior ao Tartuffo do Bro-

(13). - 2a. Carta de J. Bonifácio ao mesmo Conde de Funchal (da mesma Coleção do I. H. G. B.), fls. 1.

(14). - 1a. Carta, cit., fls. 5.

(15). - Eadem, fls. 3 .

(16). - Eadem, ibidem. 
tero; mas tem seo defeito, e h eo poetizar algum tanto, e ser filhote; no Maranhão estava hum Moço habil na materia, Vicente Jorge Dias Cabral, de q.m vi algumas Memorias, q. me agradarão. Em Mineralogia posso inculcar meo Irmão o Coronel Martim Francisco Ribeiro de Andrada, formado em Philosophia e Mathematica, e Director das Minas de S. Paulo em huma viagem mineralogica $q$. fez comigo, e o dextro Italiano Napion, deo-me m.tas esperanças, e mostrou m.to talento. Hoje está Ten.te Coronel no Brazil, hum Allemão q. veio p.a mestre da fabrica de ferro, Guilherme de Eschwege, q. aqui se deo m.to a este estudo, e o fiz viajar com esse fim por alguas partes do Reino; tem talento e activid.e; mas, q. to ao caracter, não o posso abonar despois q. se fez Barão do ci-devant Sacro Império Romano com bullas falsas (sicl). P.a a Chimica, acha-se no Brazil Jozé de Sá Betencourt e Accioli, Irmão do Camara, m.to capaz foi meo condiscipulo em Coimbra, e então mostrava mais talento q. - Irmão. Aqui está hum Moço, q. he húa joia em Chimica, ehe Alexandre Vandelli, filho do infeliz velho Domingos Vandelli, q. apezar de 90 annos de idade, e dejá estar quasi caduco, ainda assim foi julgado perigozo, e como tal jaz desterrado sem tom nem som (ilegível) o filho por experiencia de quazi tres annos o julgo $\mathrm{m}$.to habil, e o mais caapz em Chimica de q.tos conheço. Por cá ou por lá se poderão descobrir mais alguns; mas não dos q. estão em cad.ras ou estabelecim.tos novos no Rio; por q. seg.do me consta, são os pedantes, ou perfeitas Lesmas" (17).

Quando José Bonifácio escrevia estas sugestões sôbre as pesquisas científicas que se deviam atacar no Brasil, várias delas já eram positivas realidades, em Minas Gerais. E' que, enquanto o grande brasileiro se ralava por não se valer de sua licença real para regressar ao Brasil, onde, em seus sonhos mais fagueiros, como volta a escrever, havia um

\footnotetext{
"pequeno paiz, q. me convinha em Sta. Catherina, ajuntando-se-lhe os campos vizinhos da Coritiba, p.a novos estabelecim.tos de manteigas e queijos, trigos, e farinhas" (18),
}

quase todos os doutôres mineiros, seus colegas, já haviam voltado para suas terras natais, colocando-se à disposição do Govêrno da Capitania para os serviços de suas especialidades. Desde a administração de Bernardo José de Lorena (1797-1803) e durante as dos capitães-generais que se lhe seguiram, até a Independência - Pedro Maria Xa-

(17). - Eadem, fls. 3 e 4.

(18). - Eadem, fls. 5 . 
vier de Ataíde e Melo (1803-1810), D. Francisco de Assis Mascarenhas (1810-1814) e D. Manuel de Portugal e Castro (1814-1822) - acentuara-se a presença dos doutores mineiros nos vários setores da Administração, principalmente dos técnicos e cientistas.

Cabe aqui um exame mais circunstanciado da passagem dos doutores mineiros pela Administraçĩo Régia, em Minas Gerais. Vale distinguiir, antes de tudo, os trabalhos dos bacharéis em leis e em cânones, e os dos doutores em ciências naturais ou aplicadas. Os bacharéis e os padres prestam os serviços costumeiros da coisa pública, antigos como ela - os serviços da justiça, do fisco e da Igreja; os doutores em "filosofia", isto é, nas ciências naturais e aplicadas, em face das novas responsabilidades trazidas pela sua formação universitária iluminista, a inculcar como verdadeiro axioma

\footnotetext{
"que a conservação do Estado civil é a primeira e principal lei" (Ribeiro Sanches),
}

pela primeira vez serão chamados a prestar os serviços especializados de sua ciência e de sua técnica, à lembrança - como já vimos de que

"o Estado que tem terras e largos domínios, e que dêles há de tirar a sua conservação, nccessita decretar Leis para promover o trabalho e a industria" (19) (grifos nossos).

Como se vai ver, com o recrudescimento da crise aurífera, em Minas Gerais, os doutores estarão presentes em todos os setores da vida pública da Capitania, com a sua ação mais ou menos eficiente.

Para um exame do trabalho dos doutores mineiros nos últimos decênios coloniais de Minas, merece consideração especial a lista dê'es, que o memorialista Diogo Pereira Ribeiro de Vasconcelos elaborou, em 1805, para a sua "comemoração" (é o nome que lhe dá) das Pessoas Ilustres da Capitania, anexa à sua Memória da Capitania de Minas Gerais, inserta inicialmente na Revista do Instituto Histórico e Geográfico Brasileiro, e, posteriormente, na Revista do Arquivo Público Mineiro (Ano I, p. 443 a 452), cujo texto foi o de que nos valemos. Nessa lista do velho Dr. Diogo P. R. de Vasconcelos ële próprio um dos doutores de Coimbra, em Minas - podemos dividir os setores da Administração assim: o eclesiástico, com o seu pessoal da Igreja; o da justiça, com o pessoal da magistratura e dos foros cível e eclesiástico; o da fazenda, com todo o seu aparato essencialmente fiscal; o militar, com os oficiais e as tropas pagas da Capi-

(19). - Sanches (Antônio Nunes Ribriro), Cartas sôbre a educação da mocidade. Coimbra, Imprensa da Universidade (ed. Maximiano Lemos), 1922, p. 86. 
tania; e o da mineração e agricultura, com os técnicos e cientistas especializados. Há duas atividades, que poderíamos classificar como típicas de administração geral: a dos funcionários das várias repartições públicas, e a dos "técnicos em contabilidade", como tentaríamos englobar num título e numa função modernos os trabalhos de certos burocratas régios, que, desde o consulado pombalino, controlavam as contas do Govêrno.

A lista das Pessoas Ilustres da Capitania dá destaque à presença do clero na vida pública da época: são 34 situações, as do pessoal eclesiástico, assim divididas - 10 presbíteros seculares, 6 vigários, 7 religiosos e ex-religiosos, 9 prebendados, 1 bispo e 1 arcebispo. Quase todos são formados em Coimbra. Já tivemos ensejo de anotar que o chamado alto clero é constituído quase exclusivamente de padres lá diplomados, máxime em cânones. Geralmente os presbíteros não têm responsabilidades paroquiais e, como são, via de regra, homens abonados e das melhores famílias, dispõem de lazer bastante para se tornarem excelentes pregadores, escritores e clérigos de carreira; já os vigários aparecem em menor número, justamente pelos encargos da vida paroquial, que não é tão fácil; a enumeração dos religiosos - onde há o destaque do maior homem mineiro da época, Frei José Mariano da Conceição Veloso - abrange vários dêles, que, nascidos nas Minas, vivem fora delas, já que é vedada a existência de conventos ali, como foi o caso de Frei José de Santa Rita Durão; o número dos prebendados - titulares do Cabido e da Sé de Mariana - volta a acrescer-se pelas razões, semelhantes, do grupo dos presbíteros sem paróquia, pois a folga de suas vidas de Cổnegos e mais a côngrua régia que recebem dão-lhes tempo de sobra para fazerem suas carreiras diocesanas e até para futricarem a vida dos bispos mais dignos da Sede marianense, que ousarem botar a mão e o báculo em suas vidas sem grandeza. Os bacharéis em leis - justamente os "bolônios" que Pombal e seus companheiros de reforma universitária queriam ver diminuídos no Reino - são os que detêm o maior aúmero de situações na sociedade e na Administração, uma vez que, além de exercer os cargos próprios da justiça, como os de advogados, canonistas (fôro civil e eclesiástico), juízes-de-fora, ouvidores e desembargadores, ainda se arrogam o direito de ser titulares dos melhores cargos fazendários (intendentes, procuradores, provedores, etc.): a lista inclui 15 canonistas e 11 ouvidores e desembargadores, e mais a quase totalidade dos ocupantes dos altos cargos e dos especialistas em ciências contábeis; são muito particularmente os bacharéis em direito os cultorees mais destacados das letras coloniais, a começar pelo mais antigo dẹles, Cláudio Manuel da Costa, o qual, já antes de sua volta ao Brasil, praticava com as musas desde os bancos da Universidade, seguindo-se os seus colegas Tomás Antônio Gonzaga, Inácio 
José de Álvarenga Peixoto e Manuel Inácio da Silva Alvarenga, para só lembrar, com exceção do último, aquêles doutores deslembrados pelo autor das Pessoas llustres, em sua preciosa lista; por outro lado, não é bom esquecer que vários dêles, imbuídos de sua formação iluminista de servir bem à Pátria comum, irão dedicar parte de suas obras à "promoção do trabalho e da indústria", publicando livros e folhetos sôbre agricultura, economia, ciências naturais e até etnografia, como foi o caso dos Drs. José Gregório de Morais Navarro, João Evangelista de Faria Lobato e José Teixeira da Fonseca Vasconcelos. O setor fazendário não aparece senão indiretamente na lista, pois como vimos geralmente as autoridades do fisco são advogados, como, em sua absoluta maioria, são também advogados os funcionários mais ou menos categorizados. Nos quinze anos que anteccdem a morte do Conde de Linhares, de 1797 a 1812, o grupo dos técnicos e cientistas será o mais importante da Administração mineira. Ou, pelo menos, êsses doutores de Coimbra receberão tais e quais atenções, como se fôssem as pessoas mais ilustres da Capitania; num total de 34 situações, êles compõem 10 bacharéis em Filosofia e Matemática, 3 naturalistas, 4 mineralogistas, 6 botânicos, 6 conhecedores das ciências agrícolas e 5 técnicos de várias especialidades; geralmente, os 6 médicos mais conhecidos estarão ao lado dêles, assim como os militares formados (ê) ou engenheiros; se alguns dêsses cientistas escrevem bem - como é o caso do Dr. José Vieira Couto - a maior parte apenas usará das letras para a divulgação dos seus experimentos, pesquisas ou traduções; o que surpreende nesse punhado de técnicos é serem tão poucos e, ao mesmo tempo, serem dotados de tanto entusiasmo, que figuram estar em tôda a parte: cuidam da remessa de caixas de animais, insetos, plantas e minérios para a Côrte; descobrem nitreiras no sertão; exploram galena, chumbo e diamantes, em vários lugares ao mesmo tempo; apuram raças de cavalos e os remetem para as autoridades régias; orientam e instalam fábricas de fiados e tecidos; fundam fábricas de pólvora; criam e mantêm cadeiras e cursos de anatomia e cirurgia, em Vila Rica; importam folhetos sôbre as produções que podem ser tentadas na terra; cultivam "linho canhamo", trigo, centeio e outras espécies vegetais européias, inclusive frutas; estabelecem fundições de ferro, fábricas de cerâmica e plantações de algodão; escrevem trabalhos de cunho prático para ajuda da agricultura e da indústria locais; criam carneiros e lhes exploram a lã, numa indústria rural interessantíssima; e dão-se a outras atividades politécnicas, as mais variadas.

Entretanto, é preciso advertir que a obra dos cientistas mineiros pouco efeito teve sôbre a grande crise econômica que se abatera sôbre a Capitania, a partir de 1780, até os dias da Independência. Expliquemo-nos. Antes de tudo, a Administração régia - como já 
tivemos ocasião de observar - mesmo nos dias do Marquês de Pombal, não estava preparada para usar em seus problemas os processos técnicos e científicos prometidos pelas novas gerações da Universidade de Coimbra: aquêle rápido éclat da reforma de 1772 durara muito pouco e o retôrno do "reino da estupidez" sepultara nas velhas rotinas e arraigados preconceitos a esperança nos jovens doutores saídos dali. Vimos, assim, que um ou outro governador mais esclarecido tentou algumas práticas modernas, por exemplo, visando a salvação da produção do ouro. Eles foram desprezados, em Lisboa, que sòmente entendia como remédio para o mal o arrôcho fiscal, a "derrama"... E' sintomático que será o Visconde de Barbacena - o primeiro doutor em ciências pela Universidade reformada, ilustre naturalista ali e na Academia das Ciências de Lisboa - quem irá preconizar a "derrama", em 1789, desencadeando a tragédia da Inconfidência. Portanto, os doutores de Coimbra, muitos dos quais formados ainda nos primeiros dias do agravamento da: crise, não foram sequer lembrados, para ajudar em alguma coisa. Quando D. Rodrigo de Sousa Coutinho, fidalgo que continuara as mesmas generosas idéias do velho Duque de Lafões (fundador da Academia das Ciências e promotor das viagens científicas dos especialistas aos países mais adiantados da Europa) sôbre o estímulo que se deveria dar aos jovens doutores saídos de Coimbra, teve de vencer dois grandes obstáculos, em Minas Gerais: o da incompreensão dos administradores e o da falta de recursos financeiros para assistir aos trabalhos dos cientistas ali. Principalmente êstes: a Administração mineira vive naqueles dias a sua ruína financeira mais completa, pela míngua cada vez maior da produção do ouro. O Govêrno não tem numerário para acudir ans seus problemas mais prementes: quando, por exemplo, chega o aviso régio para se pagar a João Manso Pereira,

\footnotetext{
"encarregado do descobrimento das Nitreiras naturais nas barreiras da Capitania de São Paulo, depois de cuja delig.a deve passar a das Minas Gerais para trabalhar na nov Mina de Prata q. se descobriu no Abaeté", a importância de $400 \$ 000$, ordena a Rainha que "aquella penção seja paga pelo Subsidio literario da Cap.nia onde elle estiver, (...) afim de q. no pagam.to dos $400 \$$ annuais não haja confuzão, devendo o referido João Manço Pereira cobrala emdiferentes lugares" (20)...
}

O que valia dizer não haver o dinheiro em parte alguma, pois o impôsto não dava nem para pagar os magros salários dos professôres régios da Capitania! Ou então, quando o Dr. José Vieira Couto quer

(20). - Códice 278, do APM, fls. 1 e 1v، 
iniciar suas explorações pelas terras do Distrito Diamantino, o Intendente Amaral Silveira, da demarcação Diamantina, obsta os passos do cientista de tôdas as maneiras, provocando a hábil intervenção do Governador Bernardo José de Lorena (21) .

Outra dificuldade insuperável encontrada pelos doutores de 1 Coimbra em Minas foi o atraso com que principiaram êles os seus trabalhos de busca e exp'oração de novas riquezas minerais e agrícolas da terra, com o propósito de substituir a monocultura aurífera agonizante. Esse atraso ainda poderia ser superado, se houvesse um plano sistemático e objetivo elaborado pelos especialistas, reunidos todos em tôrno dêles, intensiva e extensivamente, durante anos inteiros. Infelizmente, tal não aconteceu. Não hâ notícia de qualquer promoção científica entre êsses doutores, que resulte de um trabalho de equipe: os tempos ainda estão verdes, verdíssimos, para êsses desapegos ou modéstias de cientistas... Há notícias - isso sim — de malquerenças e inimizades entre ê’es: a transcrição dos trechos daquelas cartas do mineralogista José Bonifácio bem evidencia a má vontade que reina entre êles. Debalde alguns dos. doutores ascendem aos altos postos da Administração, como Joaquim Veloso de Miranda e Diogo Pereira Ribeiro de Vasconcelos, que se sucedem no cargo de Secretáríos do Govêrno, sob as administrações de Lorena e de Ataíde e Melo, mas não se segue daí que tenham ajudado substancialmente os colegas em assuntos de suas especialidades, a serviço da causa pública. A referência do Dr. Dígo ao fato de que "he bom amigo", faz presumir ser Veloso de Miranda o padrinho de sua ascensão ao Secretariado, pois é sabido ter-se tornado êstes discípulo predileto de Domingos Vandelli um intratável misantropo, que se fechou em seu sítio do Mau Cabelo, e nunca permitiu que qualquer pessoa tivesse acesso às suas pesquisas científicas, que levou consigo para o túmulo...

Ora, se os trabalhos científicos não se efetivam dentro de um programa adrede preparado, êles irão ressentir-se de sua improvisação e descontinuidade. Embora os doutores se empenhem em seu árduo trabalho, êles estarão sempre sòzinhos, sempre a recomeçar muitas vêzes o que outros já fizeram, como é o caso das pesquisas do sertão do Rio Abaeté, antes levantadas pelo Dr. Vieira Couto e depois pelo Barão de Eschwege... A morte do Conde de Linhares, o incansável animador das pesquisas, irá levar o desânimo aos doutores mineiros, a partir de 1812: o único grande feito científico- industrial depois dessa data é a fundição de ferro de Gaspar Soares, promovida pelo Intendente Câmara. Já quase todos avançados em idade, desiludidos a estúpida burocracia da Côrte e de Vila Rica, os doutores irão refugian-

(21). - V. Códice 277, do APM, fls. 27 a $27 \mathrm{v}$. 
do-se, aos poucos, em suas propriedades e ali, no anonimato e no outono de suas vidas, irão aguardando a chegada da Parca implacável.

No fundo, êsses filhos do século, êsses contemporâneos de René - a personagem-símbolo do tempo, prêsa da "vaga das paixões", ainda mais envenenadas pela dúvida - comprazem-se nesse melancólico fim de vida, achando que tinha mesmo de ser assim. O progresso, a marcha da humanidade, cobraria êsse preço tão alto. E êles o aceitariam, como bons neoclássicos, estòicamente.

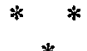

Mas, antes que o fim chegasse, vários dos doutores desenvolvimentistas - poderemos aqui pôr o adjetivo moderno, porque êles foram, na verdade, os primeiros homens dêste País que tomaram uma consciência objetiva da necessidade do desenvolvimento nacional não sòmente tinham empenhado suas vidas tão nobres a serviço da causa, mas também haviam dexado para a posteridade tôda uma literatura comprovadora do seu esfôrço científico. E' sabido que a época do Iluminismo tem fôlego curto no que toca à criação de obras grandes e originais. Sua preocupação maior é, antes, a divulgação do que a própria criação, é a expansão do saber, desvestido de sıas sutilezas ou profundidades. O liuminismo é uma era prática, utilitária.

\footnotetext{
"Quer-se saber - explicam os irmãos Grimm - mas quer-se aprender sem esfôrço e $\mathrm{cm}$ pouco tempo, o que é ,sem dúvida, a causa dos diferentes métodos que se apresentam todos os dias e a razão pela qual vemos tantos abrégés" (22).
}

Daí a grande quantidade das publicações curtas, dos "pensamentos" extraídosdas obras às vêzes exaustivas dos autores, as "análises", os "gênios" e os "espíritos", os "breviários" e os compêndios, as "biblotecas" e os dicionárics, os "almanaques", os "vademecuns". O Brasil e as Minas Gerais dos últimos decênios do século XVIII e dos princípios do século seguirte irão tomar conhecimento dessa literatura breve, utilitária e "filosófica", a que se darão os eruditos do tempo. O grande fitologista Frei José Mariano da Conceição Veloso, o mais antigo dos cientistas mineiros do Iluminismo, elabora, excepcionalmente porém, a sua monumental Flora Fluminensis (primeiros meses de 1790 ), em cujo volume de texto declara, em carta a D. Luís de Vasconcelos e Sousa,

(22). - Grimm Apud Hazard (Paul), La pensée européenne au XVIIT.ème Siècls. Paris, Boivin \& Cie., 1940, 3v., t. II, p. 187-8. 


\begin{abstract}
"ter estudado, feito desenhar e reduzido à nomenclatura de Lineu, segundo o sistema sexual, cêrca de mil e setecentos exemplares de plantas" brasileiras (23);
\end{abstract}

excepcional também, pelo volume, é o seu $O$ Fazendeiro do Brasil (1798-1806), obra de onze volumes em cinco tomos (estudos sôbre a cultura da cana e feitura do açúcar; o leite, o queijo e a manteiga: a tinturaria, com memórias sôbre o anil, cultura e fabrico do urucú, sôbre o índigo, a cultura do cacteiro e a criação da cochonilha; bebidas alimentosas; cultura do café, do cacau e preparação do chocolate; especiarias; e o último sôbre filatura, procurando, assim,

"colhêr sempre alguma luz para si e utilidade para o seu país";

depois, entram os trabalhos curtos: Extrato sôbre os engenhos de açúcar no Brasil, condensação da obra Cultura e opulência do Brasil, de Antonil (Lisboa, 1800, 120 p., in-49); Memória sôbre a cultura da urumbeba e sôbre a criação da cochonilha (Lisboa, 1799, 45 p., it1-89); Memória e extratos sôbre a pipereira negra (Lisboa, 1798. in-89); Aviário brasílico ou galeria ornitológica das aves indígenas do Brasil (Lisboa, 1800, in-fol.); Quinografia portuguêsa (coleção de memórias sôbre 22 espécies brasileiras de quinas) (Lisboa, 1799, 221 p., in-89); Alografia dos álcales fixos (Lisboa, 1798, in-49); a coletânea didática intitulada $O$ naturalista instruído nos diversos métodos, antigos e modernos, de ajuntar, preparar e conservar as produções dos três reinos da natureza (Lisboa, 1800, in-89); Relação das moedas dos países estrangeiros, com o valor de cada uma, reduzido ao dinheiro português, para uso dos comerciantes (Lisboa, 1800, 123 p., in-8\%), etc.; com as traduções, Frei Veloso revela-se o mais fecundo dos autores científicos mineiros (mais de 20 obras publicadas), se não bastasse êsse monumento máximo da ciência brasileira, que é a Flora Fluminensis. O outro Veloso, o Dr. Joaquim Veloso de Miranda, depois de promovido ao ensino universitário em Coimbra, faz jus ao cenáculo ilustre da Academia Real das Ciências de Lisboa e vai publicando. através de sua carerira científica, os seus trabalhos: Descriptio animalium quorundam brasiliensium, sôbre zoologia; Brasiliensium plantarum fasciculus e Plantarum quarundam Brasiliensium descriptio botani$\mathrm{ca}$, folhetos sôbre a botânica brasílica e, mais tarde, as Memórias de suas excursões científicas (24), tendo deixado alguns inéditos. Manuel

(23). - Stellfeld (Carlos), Os dois Vellozo. Rio de Janeiro, Gráfica Ed. Souza, 1952, p. 36 .

(24). - Blake (A. Vitorino A. Sacramento), Dicionário Bibliográfico Brasileiro. Rio de Janeiro, Tip. Nacional, 1883, 7v, t. IV, p. 251. 
Ferreira da Câmara, logo após sua formatura, publica, em 1788, um Ensaio de descrição física e econômica da Comarca dos Ilheus na América, talvez a primeira obra premiada pela Academia das Ciências de Lisboa - como presume o Sr. Marcos Carneiro de Mendonça (25) - logo seguida das Observações àcerca do carvão de pedra da Freguesia da Carvoeira, editadas no ano seguinte, obras essas que abrirão ao futuro Intendente das Minas e dos Diamantes as portas da referida Academia. O Dr. José Vieira Couto, para "inculcar suas viagens", deixa três memórias de sua especialidade e, talvez, outros trabalhos menores que se teriam perdido; de suas perquirições sôbre o salitre - a preocupação da Côrte é a manipulação da pólvora, por causa das guerras na Europa - anota uma Memória sôbre as salitreiras naturais de Monte Rorigo ou Rodrigo, na Serra do Cabral; amante extremoso da terra natal, escreve a excelente Memória sôbre as minas da Capitania de Minas Gerais, suas descriçóes, ensaios e domicílio próprio, outra Memória sôbre a Capitania de Minas Gerais, seu território, clima, produções metálicas, etc., uma Viagem ao Indaiá, e uma Memória sôbre as minas de cobalto da Capitania de Minas Gerais (26): ...

\footnotetext{
"dos sábios do seu tempo - opina o mestre Sílvio Romero, em sua História da Literatura Brasileira (27) - foi Couto um dos que mais escreveram e em melhor estilo".
}

Vicente Coelho de Seabra Silva Teles, o jovem pesquisador nascido em Congonhas do Campo, é o autor dos Elementos de Química, o primeiro

\footnotetext{
"tratado completo de química escrito em português, na doutrina anti-flogística" (Pereira Salgado) (28),
}

que alcança intensa repercussão; escreve ainda sôbre as minas de sua Capitania, sôbre pedras preciosas, mas, principalmente, a Memória sôbre os prejuízos causados pelas sepulturas dos cadáveres nos templos, e método de os prevenir (1800), que teria apressado a Carta-Régia de 14 de janeiro de 1801, que mandava construir cemitérios retirados das cidades e proibia enterros nas igrejas; ao publicar outro trabalho seu - a Memoria sôbre a cultura do arros em Portugal, e suas conquis-

(25). - Mendonça (Marcos Carneiro de), O Intendente Câmara. 2a. edição, São Paulo, Companhia Editôra Nacional (Brasiliana), 1958, p. 15.

(26). - Sacramento Blake, Dicionário..., op. «it., t. V, p. 229.

(27). - Romero (Sílvio), História da Literatura Brasileira. Nova edição, Rio de Janeiro, Livraria José Ólímpio, 1960, t. II, p. 563.

(28). - Peres (Damião), História de Portugal. Barcelos (Portugal), Portucalense Editôra, 1934, 8v, t. VI, p. 530. 
tas - também de 1800 (como o anterior, editado pela Oficina da Kasa Literária do Arco do Cego, de Lisboa, sob a direção do compatrício e amigo Frei José Mariano da Conceição Veloso), Silva Teles defende o arroz, "alimento saboroso", contra "algurs impostores", os quais,

"querendo ter de mais huma capa para a sua ignorancia, tem declarado hua injusta guerra a este proficuo, e innocente dom da provida, e benevola Natureza";

outro interessante trabalho de Vicente Coelho de Seabra Silva Teles, publicado em 1792, em Coimbra, pela Real Imprensa da Universidade, é a Memoria sobre o methodo de curar a fcrrugem das oliveiras, obra científica ilustrada pelo próprio autor, que êle dedica a D. Francisco Rafael de Castro, Reformador Reitor da Universidade de Coimbra. Mais outro médico mineiro que publica diversas obras é o Dr. Francisco de Melo Franco, o lendário autor do poema satírico Reino da Estupidez, contra o reitorado do.Principal Mendonça, que sucedeu a D. Francisco de Lemos e tentou desfazer os efeitos da reforma pombalina na Universidade de Coimbra; êle publica, em 1790, o seu Tratado de educação física dos meninosi para uso da nação portuguêas, em que há - segundo Afonso Arinos de Melo Franco -

\footnotetext{
"uma adaptação aumentada pelos sólidos conhecimentos médicos do autor, dos princípios mais aceitáveis da educação natural do Emilio, frequientemente com a citação das mesmas fontes que serviram a Rousscau" (29).
}

Nem sempre, porém, êsses mineiros vindos de Coimbra serão necessàriamente publicistas. Alguns se destacarão pela sua competência clínica e seus dotes humanitários, como é o caso do Dr. Faustino José de Azevedo, de Campanha de Princesa, que, não satisfeito com seu título de bacharel em Filosofia, de Coimbra, passou-se para Montpellier, onde conquistou o grau de Doutor em Medicina;

"chegado ao Rio de Janeiro - são palavras do jornal Astro de Minas, do dia 26 de fevereiro de 1823, fazendo-lhe o necrológio bem conhecieo o honrado patricio que obteria ali vantagens, pelo uso da Medicina, que não conseguiria no seo paiz natal (Campanha), até pela rareza de Medicos que então havia naquella cidade 「Rio de Janeiro]. Ao interesse se oppoz a mais nobre das virtudes - o amor da Patria e o desejo de ser util aos seos patricios. Deixando o Rio

(29). - O indio brasileiro e a Revolução Francesa. Rio de Jansiro, Livraria José Olímpio Editôra, 1937, p. 328-329. 
de Janeiro consagrou-se inteiramente a elles pelo espaço de mais de 32 annos [na Campanha, sua terra natal]" (30).

Outro eminente médico conimbricense, de longa tradição de homem culto em Vila Rica (esteve em Coimbra em 1743 a 1748), foi o Dr. Tomás de Aquino Belo e Freitas, que teria traduzido a Henriade, de Voltaire (Rodrigues Lapa), ao qual assim tecem as Cartas Chilenas êstes encômios:
"Há nesta grande terra um homem sábio
e o único formado em medicina.
A êste bom doutor estimam todos, por sua profissão, por seus talentos, por seu afável modo e, mais que tudo, pelas muitas virtudes que respira" (31).

O que vale recordar é que até alguns bacharéis em leis, vindos da Europa, iriam interessar-se em escrever trabalhos de divulgação científica, para ajudar a resolver os problemas que afligiam a Capitania natal. Eis que o Dr. José Gregório de Morais Navarro, que se tornaria figura lendária nos sertões do Paracatú do Príncipe, como seu primeiro Juiz-de-Fora e instalador da Vila, deixa escrito o muito útil opúsculo Discurso sobre o melhoramento da economia rustica do Brasil, pela introdução do arado, reforma das fornalhas, e conservcção de suas mattas, etc., (publicação de Frei Veloso, na Oficina de Simão Tadeu Ferreira, 1799, in-8\%, 20 p., em Lisboa), propugnando pela agricultura racional e pela proteção das florestas da terra.

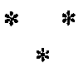

\section{NOTAS BIBLIOGRAFICAS.}

1. - BELO HORIZONTE. Arquivo Público Mineiro - Códice 211. fls. 1.

2. - Idem. fls. 2 .

3. - Idem. fls. 3.

4. - BELO HORIZONTE. Arquivo Público Mineiro - Códice 224.

5. - Códice 211, cit., fls. 105.

(30). - Azevedo, Faustino José de $A p$. Valadão (Alfredo), Campanha da Princesa. Rio de Janeiro, Leuzinger S.A., 1937-1940, 2v, t. I, p. 185.

(31). - Gonzaga (Tomás Antônio), Cartas Chilenas. Nova edição, Rio de Janeiro, Instituto Nacional do Livro (ed. M. Rodrigues Lapa), 1957, Catra XII, vv. $242-247$. 
6. - INSTRUÇÃO pra o Govêrno da Capitania de Minas Gerais. Revista do Arquivo Público Mineiro, Belo Horizonte, 8: 403.

7. - LISBOA. Biblioteca Nacional - Cartas de Bernardo José de Lorena, $n .11$. (Coleção Pombalina).

8. - SAINT_HILAIRE (Augusto de), Viagem pelas Provincias do Rio de Janeiro e Minas Gerais. Ed. Brasileira. São Paulo, Companhia Editôra Nacional, 1938. V. 1, p. 304.

9. - BELO HORIzONTE. Arquivo Público Mineiro - Códice 238. fls. 17.

10. - VARNHAGEN (Francisco Adolfo de), História Geral do Brasil. 7a. ed. São Paulo, s.d. V. 5, p. 15.

11. - ANDRADA E SILVA (José Bonifácio de), 1a. carta de José Bonifácio de Andrada e Silva ao Conde de Funchal, em 30 de julho de 1812, fls. 3. (Arquivo do Instituto Histórico e Geográfico Brasileiro, Rio de Janeiro. Doc. n. 4.845-C).

12. - Eadem, fls. 4.

13. - ANDRADA E SILVA (José Bonifácio de), 2a. carta de José Bonifácio de Andrada e Silva ao Conde de Funchal. fl. 1. (Arquivo do Instituto Histórico e Geográfico Brasileiro, Rio de Janeiro. Doc. n. 4.845-C).

14. - 1a. carta, cit., fls. 5 .

15. - Eadem, fls. 3.

16. - Eadem, ibidem.

17. - Eadem, fls. 3 e 4 .

18. - Eadem, fls. 5.

19. - SANCHES (Antônio Nunes Ribeiro), Cartas sôbre a educação da mocidade. Coimbra, Imprensa da Universidade, 1922. p. 86.

20. - BELO HORIzONTE. Arquivo Público Mineiro - Códice 279. fls. 1 e 1v.

21. - BELO hORIZONTE. Arquivo Público Mineiro - Códice 277. fls. 27 a 27v. 